\title{
An Exploration of a Systematic and Effective Mechanism of Delivering Feedback on EFL Student Writing*
}

\author{
SU Yan-fei \\ Sichuan University of Arts and Science, Dazhou, China
}

\begin{abstract}
In China, it is widely believed that teacher feedback plays a crucial role in EFL writing course, exerting a great impact on the improvement of Chinese EFL students' writing abilities so that teachers have been required to deliver feedback on students' writings. Teachers, consequently, spare no pains to give feedback, expecting their students would make progress in their writing, but it seems that things go contrary to their wishes. Although there are various complicated factors contributing to the situation, one of the important factors lies in the teachers, a number of whom do not grasp a systematic and effective mechanism of delivering feedback on EFL student writing. Much importance has been attached to Chinese EFL student writing, however, rare attention has been paid to conducting research on concrete ways of delivering feedback on Chinese EFL student writing in China. Therefore, this paper serves to fill the gap, mainly devoting itself to exploring concrete methods of delivering teacher feedback on EFL student writing.
\end{abstract}

Keywords: teacher feedback, EFL student writing, a systematic and effective mechanism

\section{Introduction}

Feedback is of great significance to EFL students. Two mainstream types of feedback have attracted much attention and hot discussion of teachers and scholars in the field of EFL writing for a long time, namely, peer feedback and teacher feedback. Herein peer feedback is also called peer review/response, which means any comments given by one student to another for revising the writing, while teacher feedback is also called teacher response, which means any comments given by a teacher to a student for revising the writing. Since research about teacher feedback on EFL student writing has been started, scholars hold different opinions about its effectiveness in terms of helping EFL students improve their writings, with some believing it effective (Eksi, 2012; Srichanyachon, 2011) and some ineffective (Truscott, 1996). Nonetheless, it seems that the number of people holding positive view outnumbers those holding negative one. Furthermore, as far as whether teacher feedback is superior to peer feedback is concerned, a heated discussion has been conducted, whereas a consensus has yet been reached. However, it seems that the idea that both teacher feedback and peer feedback play a part in EFL writing gains the upper hand.

In China, after the Reform and Opening-up Policy being carried out and with the globalization being deepened, frequent exchanges and cooperation between China and western countries have been increasingly

\footnotetext{
* Acknowledgements: This paper is supported by Sichuan University of Arts and Science (Grant No.: 2015GJ016Y). Heartfelt gratitude goes to Dr. Cheung Yin Ling, an Assistant Professor of English Language and Literature at the National Institute of Education, Nanyang Technological University, Singapore, for her valuable and helpful suggestions when I studied in NIE.

SU Yan-fei, lecturer, M.A., School of Foreign Languages, Sichuan University of Arts and Science.
} 
conducted and enhanced. The importance of English as a Foreign Language (EFL) in China has been widely recognized so that EFL teaching in China enjoys a boom. EFL writing course is an indispensable part in EFL teaching curriculum. In China, it is believed that teacher feedback is of great importance in helping Chinese EFL students improve their writing abilities so that writing teachers are required to provide feedback on students' writings. Teachers and scholars have committed themselves to conducting research in the field of EFL writing, expecting to improve their EFL writing teaching and help EFL students make progress in EFL writing. However, rare attention has been paid to concrete ways of delivering feedback on Chinese EFL student writing in China. Numerous EFL writing teachers did not receive the training of how to deliver a systematic and effective feedback on EFL student writing. For instance, as an English teacher working at a tier-3 university (there is a hierarchy of tertiary education in China, which could be generally divided into distinguished universities as tier-1, major universities as tier-2, and nobody universities as tier-3), the author was not trained to give feedback on student writing, did not reflect on it, and did not read papers in this regard until this paper was written, while the author gave feedback based on her experience, at her convenience or in her interest. It is seemingly possible that a majority of EFL writing teachers at tier-3 universities share similar experiences. Consequently, EFL writing teachers make great efforts to deliver feedback on student writing, but it seems that students do not make great progress in EFL writing. Therefore, a profound reflection and exploration of teacher feedback on EFL student writing is needed and a systematic and effective mechanism of delivering feedback should be proposed to guide EFL writing teachers to give feedback.

\section{Literature Review}

Numerous studies have been conducted in different countries (for instance, Bangkok, Turkey, Japan, and China) in terms of delivering teacher feedback on EFL/ESL student writing (Bitchener, Young, \& Cameron, 2005; Chiang, 2004; Eksi, 2012; Elwood \& Bode, 2014; Ferris, 1995; Ferris, 1997; Lee, 2008; Muncie, 2000; Nurmukhamedov, 2009; Srichanyachon, 2011; Yang, Badger, \& Yu, 2006), which could be generally divided into four perspectives as follows: comparing peer review and teacher feedback, students' attitudes towards teacher feedback, effectiveness of teacher feedback, and factors affecting teacher feedback. Nonetheless, few studies have been committed to a systematic and effective mechanism of giving teacher feedback on EFL student writing in China, but to certain aspect of delivering teacher feedback.

Some scholars have done research on comparing peer review and teacher feedback (Eksi, 2012; Srichanyachon, 2011; Yang, Badger, \& Yu, 2006). Yang, Badger, and Yu (2006) were devoted themselves to peer review and teacher feedback in tertiary education in China, investigating two groups of students writing an essay on the same topic, one getting teacher feedback and another getting peer feedback, with results showing that those Chinese students prefer teacher feedback to peer feedback, although the two types of feedback do help them improve their writing and are valued. Srichanyachon (2011) compared self-revision, peer revision, and teacher revision of student writing at a Bangkok university and got the results that teacher revision was indispensable, learners preferred teacher revision and believed peer feedback was useful. Investigating peer review and teacher feedback at a Turkey university, Eksi (2012) found that teacher feedback and peer review were effective and peer review could be used as a critical alternative to reduce teacher's workload.

Great energy has been invested in studying effectiveness of teacher feedback and factors influencing teacher feedback on EFL/ESL student writing (Bitchener, Young, \& Cameron, 2005; Ferris, 1997; Lee, 2008; Muncie, 2000; Nurmukhamedov, 2009). Lee (2008) researched 26 Hong Kong secondary English teachers' 
written feedback on 174 students' writings, finding out various factors impacting teachers' written feedback, namely, teachers' beliefs, values, understandings, and knowledge and philosophies about feedback and attitude towards exams and politics. Nurmukhamedov (2009) discussed different types and modes of feedback on student writing and their merits and demerits respectively, covering pen-and-paper, inserting comment/track change and using audio. Muncie (2000) mentioned how teachers held students responsible for using teacher feedback. Bitchener, Young, and Cameron (2005) investigated whether certain types of feedback were effective for improving ESL students' writing accuracy, with results varying from occasion to occasion. Ferris (1997) conducted research on impact of teacher's marginal and end comments on advanced university ESL students' revision of writing and found that students did conduct revisions according to teacher feedback.

No matter whether it is teacher feedback or peer feedback, their target object is student's writing, in which the student is the subject. Student's attitude towards teacher feedback and peer feedback is of critical importance. Therefore, some previous studies have devoted themselves to studying students' attitudes towards teacher feedback (Chiang, 2004; Elwood \& Bode, 2014; Ferris, 1995). Chiang (2004) analyzed students' attitudes towards teacher feedback, finding that the majority of students believed teacher feedback was important and valued teacher feedback and implying that the ineffectiveness of teacher feedback might insist in the ways of giving feedback instead of feedback itself. Elwood and Bode (2014) conducted an examination of students' perceptions and preferences about teacher feedback in a Japanese university writing class, with results showing that Japanese students generally responded positively to teacher feedback and responses varied from students with higher proficiency to those with lower proficiency. Studying ESL university students' responding to teacher feedback on preliminary versus final drafts of their writings, Ferris (1995) found that students in general took teacher feedback seriously and made response to the feedback.

According to the above-mentioned literature review, teacher feedback on EFL/ESL student writing does appreciate its effectiveness for the improvement of students' writing abilities to some extent and a majority of students do prefer teacher feedback to peer feedback. Therefore, it is a task of priority for both researchers and teachers in the field of EFL writing to conduct research on how to systematically and effectively deliver teacher feedback on student writing in order to help EFL students make substantial progress in EFL writing.

\section{Discussion and Implication}

Teacher feedback on EFL student writing is inspiring and beneficial to students if it is given effectively and systematically, otherwise it would be a de-motivator. Therefore, EFL writing teachers should attach great attention to grasping a systematic and effective mechanism of delivering feedback on EFL student writing. In particular, as an English teacher at a tier-3 university in China, teachers should pour great efforts into helping Chinese EFL students with low-proficiency make improvement in writing as much as possible. Usually, a majority of Chinese EFL writing teachers gave feedback on student writing in ways of utilizing their experience, imitating their former EFL teachers' methods or learning from their colleagues. The ways of offering feedback on student writing was mainly limited to word spelling, usage of collocations or grammar, but rarely about idea or organization of the writing. Moreover, rare attention has been paid to how to deliver feedback. There are many factors influencing teacher feedback such as over-loaded work, large class size, being lack of systematic training, without institutional support, and the most important one without an awareness of a systematic and effective mechanism of delivering feedback. Many teachers held the belief that most students do not need various types of feedback because they usually do not have high level of English proficiency, and if they are 
unable to write a correct sentence, how can you expect them to pay attention to content or organization of their writing? Moreover, many Chinese EFL writing teachers did not reflect on how to give a systematic and effective feedback.

However, the author has gained a new insight into teacher feedback on EFL student writing after reading relevant literature. A small-scale analysis of teacher feedback on EFL writing and a brief summarization of methods concerning delivering teacher feedback according to the above-mentioned literature were conducted. Hopefully, EFL writing teachers will reflect on their feedback given to student writing, learn from the following summarized methods of delivering feedback, and apply them into their future feedback. The list of systematic and effective mechanism of how teachers deliver feedback on EFL student writing is presented as follows (Bitchener, Young, \& Cameron, 2005; Chiang, 2004; Elwood \& Bode, 2014; Ferris, 1997; Ferris, 2007; Lee, 2008; Nurmukhamedov, 2009):

(1) Explaining explicitly written correction codes, symbols, meta-linguistic terminologies, and the grading criteria to students;

(2) Having a clear idea of certain grading criteria including popular and university-specific criteria;

(3) Reading through student writing from start to end as the first step;

(4) Focusing on form: vocabulary (spelling, word usage, or choice, collocation), grammar (tense, subject-verb agreement, inflectional suffix, or sentence fragments);

(5) Focusing on content: organization, idea, structure, or rhetoric;

(6) Focusing on single or multiple draft(s);

(7) Giving direct feedback: identifying an error and providing corresponding correct answer;

(8) Giving indirect feedback: just indicating an error by giving editing symbols (labeling) such as circle, underline, code, or mark and leaving students themselves to correct it, or by making a request, a question, a statement, an imperative;

(9) Giving comprehensive or selective, prioritized correction;

(10) Writing a combination of negative and positive comments;

(11) Giving specific feedback instead of vague feedback;

(12) Giving personalized or generic feedback;

(13) Avoiding appropriation by holding student-teacher conference or cyber tutoring for a face-to-face discussion, question, and answer;

(14) Giving marginal, end, or cover commentary;

(15) Holding students accountable for utilizing teacher feedback such as giving them time and space in class or student-teacher conference to read the feedback, ask questions, make revision, and require a revision-and-resubmit paper;

(16) Evaluating one's own feedback and its effectiveness at regular intervals and making a change if necessary in the future;

(17) Choosing clear hand-written, computer-aided, or oral feedback;

(18) Choosing the color of feedback: red, blue, black, gray, green, and the like;

(19) Choosing to write feedback on the manuscript of student writing or on a separate paper.

To begin with, there are various strategies covering both contents and ways of delivering feedback on EFL writing, some of which do not work alone for certain students under certain contexts, so teachers' utilization of strategies should vary from stages of writing, levels of student's English proficiency, students' gender, 
purposes of writing to types of writing. Secondly, these strategies are not linear but recursive, that is, teachers could use a certain strategy or a certain combination of strategies and also return back to find suitable strategies at any time while utilizing strategies of delivering feedback on EFL student writing flexibly. Thirdly, teachers are advised to design their own action research projects on the basis of these strategies to confirm whether certain strategies or combination of strategies would be applicable and useful in specific contexts. Last but not least, it is advisable that a training program or a workshop for pre-service and in-service writing teachers concerning how to deliver teacher feedback on EFL student writing should be organized (Ferris, 2007).

\section{Conclusion}

It is generally acknowledged that teacher feedback on EFL student writing is indispensable to help EFL students make progress in their EFL writing. However, a large number of Chinese EFL writing teachers delivered feedback on student writing according to nothing but their own experience, which is unlikely to be considered as being systematic and effective, and did not reflect on its effectiveness. Furthermore, "experience alone will not make a teacher an effective responder, but solid principles, useful techniques, and thoughtful reflection and evaluation probably will" (Ferris, 2007, p. 179). Rare attention was attached to the research of a systematic and effective teacher feedback on EFL student writing. Therefore, from the perspectives of preparation for giving feedback, types of feedback, specific ways of delivering feedback and follow-up work after delivering feedback, this paper fills the gap by making a summary of strategies about delivering teacher feedback on EFL student writing in different countries via literature review and proposing a list of recursive, comprehensive mechanism of giving feedback on EFL student writing. Although this paper is a small-scale analysis of teacher feedback, it is expected to be beneficial to both EFL writing teachers and students. In the future, a large-scale analysis of teacher feedback on EFL writing and growing action research projects based on the mechanism will be appreciated.

\section{References}

Bitchener, J., Young, S., \& Cameron, D. (2005). The effect of different types of corrective feedback on ESL student writing. Journal of Second Language Writing, 14, 191-205.

Chiang, K. K. (2004). An investigation into students' preferences for and responses to teacher feedback and its implications for writing teachers. Hong Kong Teachers' Centre Journal, 3, 98-115.

Eksi, G. Y. (2012). Peer review versus teacher feedback in process writing: How effective? International Journal of Applied Educational Studies, $\quad 13(1), \quad 33-48 . \quad$ Retrieved from http://go.galegroup.com.libproxy.nie.edu.sg/ps/i.do?action=interpret\&id=GALE\%7CA297715820\&v=2.1\&u=nie\&it=r\&p= AONE\&sw=w\&authCount $=1$ \# contentcontainer

Elwood, J. A., \& Bode, J. (2014). Student preferences vis-à-vis teacher feedback in university EFL writing classes in Japan. System, 42, 333-343.

Ferris, D. (1995). Student reactions to teacher response in multiple-draft composition classrooms. TESOL Quarterly, 29(1), 33-53.

Ferris, D. (1997). The influence of teacher commentary on student revision. TESOL Quarterly, 31(2), 315-339.

Ferris, D. (2007). Preparing teachers to respond to student writing. Journal of Second Language Writing, 16, 165-193.

Lee, I. (2008). Understanding teachers' written feedback practices in Hong Kong secondary classrooms. Journal of Second Language Writing, 17(2), 69-85.

Muncie, J. (2000). Using written teacher feedback in EFL composition classes. ELT Journal, 54(1), 47-53.

Nurmukhamedov, U. (2009). Teacher feedback on writing: Considering the options. Writing \& Pedagogy, 1(1), 113-124.

Srichanyachon, N. (2011). A comparative study of three revision methods in EFL writing. Journal of College Teaching and Learning, 8(9), 1-8. 
Truscott, J. (1996). The case for "The Case for Grammar Correction in L2 Writing Classes": A response to Ferris. Journal of Second Language Writing, 8, 111-122.

Yang, M., Badger, R., \& Yu, Z. (2006). A comparative study of peer and teacher feedback in a Chinese EFL writing class. Journal of Second Language Writing, 15, 179-200. 